\title{
Guds omskiftelighed eller Guds bevægelighed?
}

\section{Professor Niels Henrik Gregersen}

Niels Grønkjær, Den nye Gud: Efter fundamentalisme og ateisme, København: Forlaget ANIS 2010. 320 s. Kr. 289.

Abstract: This review argues that there are two incompatible lines of argument in Niels Grønkjær's interesting book on Den nye Gud [The New God: After Fundamentalism and Atheism]. The first line suggests a purely temporal understanding of the Trinity: The Father gives up his power, then both Son and Father die on the cross, while only the Spirit persists in the human community of love. The second line of thought represents an Augustinian model of Trinity, reformulated via Hegel. It seems that only the second line can fulfill the author's intentions.

Key words: Augustine - Blumenberg - Grønkjær - Hegel - Time - Trinity - Vattimo.

Niels Grønkjærs bog om den nye Gud har med rette påkaldt sig opmærksomhed. Der er tale om en yderst velskrevet bog, der forholder sig til både teologiske og kulturelle kernespørgsmål og gør det i en essayistisk stil med en personligt engageret stemmeføring.

Bogen (alle henvisninger hertil) er bygget op i tre dele: Faderens Rige (55-126,), Sønnens Rige (127-194) og Åndens Rige (195-283). De to første dele fortæller den historie, at der foregår en indre kamp mellem den voldelige Fader og den gode, men svage Søn. Faderen må opgive sit voldelige projekt, for at "den nye Gud” kan få plads - ligesom også Sønnen på korset må dø for at give plads til Ånden i kærlighedens fællesskab. Del III om Åndens Rige indeholder derimod en nærmest klassisk augustinsk version af treenighedslæren: "Faderen og sønnen er fælles i det tredje som er helligånden. Gud er disse tre.... Faderen og sønnen forenes i ånden. Nu er det endelig slut med indbyrdes rivaliseringer. Faderen er ikke isoleret i sin himmel, og sønnen er ikke ensom på sit kors. De er forbundet af kærlighedens bånd, ånden" (197). 
Der er således to forskellige opfattelser af treenighedslæren på spil hos Grønkjær, og jeg mener ikke, at de er forenelige. Den første linje indeholder en rent tidslig forståelse af forholdet mellem Fader, Søn og Helligånd. Først den ene, så den anden, så den tredje: Trip trap træsko. Den ene (sønnen) overvinder den anden (faderen) i en slags indre duel i Guds sind. Den anden model er anderledes fredelig og bygger på en forståelse af Guds evighed, som Grønkjær introducerer midt i bogen (121-126). Her tales der om et evigt eksisterende fællesskab mellem Gud Fader, Søn og Helligånd, som folder sig ud i historien, når Faderen viser sig som kærligheden almagt i Sønnens afmagt og når Sønnen genrejses af Helligåndens kraft. Her overvindes Faderen ikke, heller ikke forsvinder Sønnen til fordel for Ånden og historien. Det er den treenige Gud, der bevæger alting og som selv bevæges af fællesskabet med mennesker i Helligåndens Rige. Jeg vil mene, at kun denne anden tankelinje er i stand til at forløse Grønkjærs teologiske anliggende.

\section{Den omskiftelige Gud: Vattimo-Blumenberg-linjen}

Grønkjær er præst i Vartov, men har i mange år været lektor i etik og religionsvidenskab på Aarhus Universitet. Efter disputatsen om Augustin, Kristendom mellem gnosis og ortodoksi (2002), har han arbejdet videre med navnlig Gianni Vattimo (f. 1936) og Hans Blumenberg (1920-1996). Vattimo er som bekendt fortaler for en "svag tænkning", der i forlængelse af Nietzsche opløser alle strukturer (Gud-verden, objektivt-subjektivt osv.) til fordel for en historisk tænkning, hvor alt er led i flydende fortolkningsprocesser. Selv opfatter Vattimo denne bevægelse som igangsat af tanken om Guds inkarnation: "det eneste store paradoks og den eneste store forargelse ved den kristne åbenbaring er netop Guds inkarnation, og det vil sige afkaldet på alle disse transcendente, uforståelige, og, tror jeg, bizarre karakteristika, som alligevel i så stor grad har påvirket 'springets' teoretikere". ${ }^{1}$ På samme måde afskediger Grønkjær først den negative teologi (som siger, at ikke alt kan vides om Gud) og derpå paradoksteologien, som siger, at Gud og verden ikke kan skrives på samme formel, men må holdes sammen i troen (16-17). For Grønkjær er troen imidlertid selv en "vidensform" (18).

Afvisning af den negative eller apofatiske teologi skal dog vise sig problematisk, hvad der navnlig bliver tydeligt ved Grønkjærs anvendelse af Blumenberg. For mens Vattimo repræsenterer en venliggjort 
kristendom, hvor der ikke længere er forskel på Gud og historien, repræsenterer Blumenberg en anderledes kynisk kritik af kristendommens fallit. Allerede i sit tidlige hovedværk, Legitimität der Neuzeit fra 1966, gjorde Blumenberg gældende, at sekulariseringen ikke skal forstås som en frugt af kristendommen, sådan som teologen Friedrich Gogarten (og senere Vattimo) mente. Tværtimod finder vi fra renæssancetænkeren Bruno og fremefter et humanistisk opgør med nominalismens idé om Guds skjulte vilje og almagt. I sine senere arbejder, ikke mindst Matthäuspassion fra 1988, peger Blumenberg på det tragiske i humanismens selvtillid, alt imens han fortsætter sit kritiske arbejde med de jødisk-kristne myter: "Gud vidste ikke, hvad han gjorde, da han skabte verden", ligesom Gud "frygtede" for, at mennesket ved at spise af æblet skulle blive en farlig konkurrent til det guddommelige udødelighedsmonopol. Og når det til sidst viser sig, at det ikke lykkes for Gud at opretholde sin magt over mennesket, så bevæger Gud sig fra fornærmelse og skinsyge til korsets bevidsthed om fallit. ${ }^{2}$

Den, der har læst de første 100 sider af Grønkjærs bog, vil genkende tankegangen. Men hvor Blumenberg læser de bibelske traditioner som udtryk for idéhistoriske konstellationer, tager Grønkjær dem til indtægt for en teologisk lære om Guds selvudvikling. Og hvad Blumenberg forstår som tåbelighedens metaforik, opfatter Grønkjær som en del af troens viden om Gud. Grønkjær præsenterer således et medvidende portræt af alle Guds kvaler med skaberværket: "Gud er (jo) som os, og vi er jo som Gud... Hvis vi ligner Gud er det vel på samme måde for ham: også han må forstå sig selv i kraft af noget andet end sig selv. Derfor må Gud skabe verden og mennesket" (75). Hvad der gælder fædre og børn i almindelighed, gælder også for Gud og menneske (43-44; 57-58). Grønkjær er hverken tynget af billedforbuddet eller af den apofatiske teologis reservationer. Han taler meget ligefremt om, hvad Gud forstod og ikke forstod før verdens skabelse, og om Guds besvær med at "overtale sig selv til at tro at produktet af hver enkelt skabelsesdag er godt, og at det hele er såre godt" (63). Faktisk kunne Gud ikke "bære at indrømme at skaberværket ikke var så godt som han havde villet overtale sig selv til at tro" (63), hvorfor han måtte give mennesket skylden for sin egen utilstrækkelighed som skaber: "Menneskets gudbilledlighed er Guds undskyldning for at han i sit ansvar for skabelsen ikke kan lastes for skylden for at det gik galt. Den må mennesket bære. Alene” (71-72). Men

2. Hans Blumenberg, Matthauspassion, Frankfurt /M.: Suhrkamp 1988, 124 og 29. Se også 15: "Den fornarmede Gud, det er udgangstesen, bliver til den mislykkede Gud. At almagten forfejler sin gudværdige intention med verden - og ikke blot bryder sammen ved verden, men $i$ den - er passionens tema”. Overs. efter Ulrik Houlind Rasmussen, Hans Blumenberg, København: ANIS 2007, 165. 
måske er skabelsen snarere et makværk, et udslag af "skabergudens himmelråbende inkompetence"? (78)

Det skal siges til Grønkjærs forsvar, at han med mellemrum markerer en vis distance, når han fortæller sin læser, hvordan Gud ligesom har det med sig selv. Der er en del måske’er og spørgsmålstegn i teksten, og man kunne måske argumentere for, at den causerende stil i sig selv indeholder en vis apofatisk bevidsthed. Alligevel er det ikke indtrykket af reverens og selvironi, der melder sig under læsningen, men en sær blanding af nonchalance og bedreviden. Gud fremstilles som den, der først giver sig i kast med skabelsens glansnummer, derefter frygter for menneskets selvhævdelse og tyr til den magtfulde udstødelse af paradiset, hvorefter Gud bliver ked af det igen, og endda angrer - og derfor til sidst vælger at svække sin egen magt (76-79).

Grønkjærs beskrivelse af Guds traumatiske problemer med sit skaberværk (først magt, derpå smerte, til sidst anger) gentager sig i tolkningen af inkarnationen: "Gud giver afkald på at være en ophøjet almægtig Gud fordi han indser at han ikke med vold og magt kan opretholde en bestandig relation til mennesket. Hans styrke består nu i at han selv svækker sin magtposition for at hengive sig til og for det menneskelige" (151). Er der her tale om ligefrem forandring i Guds sindelag fra tidspunkt 1 til tidspunkt 2 og 3 ? Eller er der tale om en vilje til selvkommunikation, der altid har præget den treenige Guds liv? Det får man ikke helt besked på, fordi Grønkjær skiftevis tænker psykologisk-temporalt og teologisk-trinitarisk.

Denne uafgjorthed genfinder vi i et nervepunkt, tolkningen af Jesu korsdød. Det er Gud selv, der dør af kærlighed til skabningen. Så meget står klart. Men det afgørende teologiske spørgsmål er, om Faderen (og Helligånden) dør på samme måde som Sønnen gør. Her siger Grønkjær: "De mister hinanden. Gud selv splittes. Det gammeltestamentlige citat som Jesus udskriger på korset 'Min Gud, min Gud, hvorfor har du forladt mig?', betyder måske ikke bare at han i dødens stund bliver forladt af sin fader, men at Gud har forladt ham ved selv at dø, således at han må dø det gudløse menneskes død" (163). Ja, Faderen lider med Sønnen og lider tab. Men dør Faderen sammen med Sønnen? Det mener Grønkjær vistnok ("måske”). Men der er gode grunde til, at man aldrig har talt sådan i teologien. Faderen er hele guddommens kilde (fons deitatis) - ophører kilden, så ophører også floden. Og Helligånden er både livgiveren og fuldenderen - ophører livgiveren, så ophører livet og der er ingen fremtid. Derfor gælder princippet: Unus ex trinitate incarnatus et mortuus est.

Grønkjærs udredninger af omskiftelserne i Guds følelsesliv fylder meget i bogen. Men er det ikke et intellektuelt faux pas at drage direkte slutninger fra forskellige bibelske tekster til forskellige svingnin- 
ger i Guds psyke? Mon dog ikke ændringerne snarere kunne ligge i menneskehedens foranderlige gudsforestillinger? Man kommer til at savne en nøgtern historisk-kritisk bevidsthed. Men heller ikke teologisk er det holdbart at lade "den nye Gud" (som er svag men kærlig) erstatte den gamle Gud (som var stærk men voldelig). For hvis ikke Guds vilje og kraft var intakt, så ville opstandelsen - "kærlighedsdødens overvindelse af adskillelsesdøden” (193) - ikke være mulig.

\section{Den bevægelige Treenighed: Augustin-Hegel linjen}

Det er faktisk en sjældenhed, at nogen taler så flot og frit om opstandelse, som Niels Grønkjær gør i bogen. Opstandelsen er for Grønkjær hverken en "Zusatzmythos" (Niklas Luhmann), der bør lægges til side, eller en fortidig hhv. fremtidig hændelse. Der er derimod tale om menneskets fortsatte inddragelse i Guds liv, en deltagelse i den bevægelse, som Guds evige liv er. Derfor kan Bach i Matthauspassionen lade koret synge: Når jeg skiller mig fra dig, så skil dig ej fra mig (171). Det er Gud, der handler, når vi ikke selv kan gøre noget. "Opstandelsen udspringer af den gennemgribende bevægelse som finder sted i Gud selv" (191). Tilsvarende tilsiger troen på kødets opstandelse, at "mennesket med sine samlede livserfaringer altid har en fremtid" (190).

Denne forståelse af opstandelsens nye liv er organisk forbundet med en treenighedslære af klassisk afstøbning. For kun igennem Guds evige liv kan mennesket vinde sin identitet. Den eneste "identitet”, der findes, er den, der lever i bevægelsen mellem Faderen og Sønnen, formidlet af Helligånden. Fra Augustin hentes således opfattelsen af Helligånden som vinculum charitatis, kærlighedens bindeled mellem Fader og Søn.

Læser man bogen bagfra, fra Del III om Helligåndens Rige, viser sammenhængen mellem soteriologi og treenighedslære sig tydeligt. Men den er forberedt allerede tidligere i bogen. I troens vidensform ser mennesket sig som "forbundet med Gud og den verden han har skabt" (21). Troens vidensform drejer sig her ikke om at have indsigt Guds indre rørelser, men om forbundetheden med Gud. Tilsvarende deler Gud i skabelsen ud af sig selv, hvorved Gud både giver plads for andetheden og realiserer sig selv som kærlighedens magt: "I skabelsen både begrænser og viderefører Gud sig selv... Han kunne ikke være forblevet den samme hvis han ikke var blevet en anden" (80). Den levende Gud er altså i stadig bevægelse ud mod verden, men bliver ikke dermed en ganske anden, ikke en splinterny Gud. Samtidig reformulerer Grønkjær den klassiske skelnen fra Nikænum mellem skabt og 
fodt: "Verden er Guds andet, hans fremmede andet der ikke er af samme væsen som han; den er skabt. Sønnen er også Guds andet, men hans eget andet fordi han netop er af samme væsen som faderen hvad man jo er når man er født af nogen” (82-83). Hermed afvises både Vattimos opløsning af Guds transcendens og Blumenbergs afvisning af Guds førstehed. De steder, hvor Grønkjær langer ud efter "teismen", er det vistnok mest opfattelsen af Gud som en separat gud uden for verden, der er genstand for en kritik (selvom begrebet bruges flimrende). Men sidst i bogen taler Grønkjær uforblommet om Gud som "det absolutte", fordi Gud "frembringer sig selv som ånd ved at forholde sig til sig selv og til noget andet end sig selv. Gud indeholder i sig selv denne bevægelse" (292). Her springer Grønkjær ud som en klassisk hegelianer. I engelsk-sproget litteratur ville Grønkjærs position blive læst som et eksempel på en såkaldt infinity-based theism (da begrebet "teisme" på engelsk normalt bruges om alle former for monoteistisk gudstro). Men under alle omstændigheder er vi her milevidt fra Vattimos bløde hegelianisme, der ser det sekulariserede menneske som historiens fortolker og agent.

Grønkjær ender sågar i en beskrivelse af treenigheden, som peger på den afgørende forskel på Guds og menneskets identitet, at "Gud $i$ sig selv er på det rene [med sine relationer], hvad mennesket ikke uden videre er" (304). Her er vi hinsides alle psykologiske beskrivelser af Guds Werdegang. Og hvor Grønkjær i begyndelsen siger, at Gud er tilværelsens kilde, men derimod afviser talen om Gud som tilværelsens grund, så læser vi nu: "I grunden er Gud bevægelig" (305). For Gud er ikke en forskelsløs kilde, men et differentieret liv, der til stadighed skænker ud af sig selv for mødes med verden. Derfor er mysteriet så at sige flyttet ind i historien. Mens Grønkjær begyndte bogen med at afvise, at der findes mere end menneskene kan sige sig selv og hinanden (16), så lyder bogens sidste sætning: "Den levende Gud er virkelig fordi han giver sig selv til os. Han har til stadighed mere at sige fordi der altid er mere at sige..." (309).

Bogen anbefales som inspiration og udfordring for de dannede blandt religionens velvillige tvivlere. Men læs den til enden. Nøjes man med de første 100 sider, støder man sig på de psykologiske karikaturer. Læser man derimod bogen bagfra, præsenteres læseren for et samlet bud på en forståelse af Guds bevægelse og rummelighed. Sandelig, metafysikken er ikke forsvundet. Den er derimod "forvunden", dvs. relanceret i en tankegang, hvor Gud og menneske ikke længere står over for hinanden, men lever dybt forbundne. Midt i tilværelsen. 